\title{
Adsorpsi Metilen Biru dan Kongo Merah pada Zeolit-X Hasil Sintesis dari Abu Dasar
}

\author{
Nurul Widiastuti ${ }^{1}$, Tri A. Setiawan ${ }^{2}$, Haris $^{3}$, Endang P. Setyaningsih ${ }^{4}$ \\ ${ }^{1}$ Departemen Kimia, Fakultas Sains, Institut Teknologi Sepuluh Nopember, Surabaya, Email: \\ nurul_widiastuti@chem.its.ac.id \\ ${ }^{2}$ Departemen Kimia, Fakutas Sains, Institut Teknologi Sepuluh Nopember, Surabaya, Email: \\ triadisetiawan_adi@yahoo.com \\ ${ }^{3}$ Departemen Kimia, Fakultas Sains, Institut Teknologi Sepuluh Nopember, Surabaya, Email: \\ mochammad.harists.f@gmail.com \\ ${ }^{4}$ Departemen Kimia, Fakultas Sains, Institut Teknologi Sepuluh Nopember, Surabaya, Email: \\ endang@chem.its.ac.id
}

\begin{abstract}
This study aims to determine the adsorption capacity of methylene blue and red congo on zeolite-X synthesized from bottom ash. The zeolite-X adsorbent is synthesized from bottom ash by the smelting method using $\mathrm{NaOH}$ at $750^{\circ} \mathrm{C}$ in the atmosphere. The results of zeolite-X characterization from bottom ash were compared with zeolite$\mathrm{X}$ synthesized from pure material. The crystallinity and surface area of zeolite-X from bottom ash is still lower than zeolite-X synthesized from pure material. The surface area of zeolite-X from bottom ash is $250,850 \mathrm{~m}^{2} / \mathrm{g}$, while zeolite-X from pure material is $472,471 \mathrm{~m}^{2} / \mathrm{g}$. The results of the zeolite-X adsorption capacity from the bottom ash for methylene blue and red congo were $131.6973 \mathrm{mg} / \mathrm{g}$ and $38.12684 \mathrm{mg} / \mathrm{g}$, respectively. The adsorption process follows the Langmuir isothermal equation by following a pseudo-second-order adsorption kinetics model. Thermodynamic studies indicate that the adsorption process occurs exothermic and is spontaneous at each temperature.
\end{abstract}

Keywords: Basic Ash, Zeolite-X, Adsorption, Methylene Blue, Red Congo

\begin{abstract}
Abstrak
Penelitian ini bertujuan untuk menentukan kapasitas adsorpsi metilen biru dan kongo merah pada zeolit-X yang disintesis dari abu dasar. Adsorben zeolite-X disintesis dari abu dasar dengan metode peleburan menggunakan $\mathrm{NaOH}$ pada suhu $750^{\circ} \mathrm{C}$ dalam atmosfer udara. Hasil karakterisasi zeolit-X dari abu dasar dibandingkan dengan zeolit-X yang disintesis dari bahan murni. Kristalinitas dan luas permukaan zeolit-X dari abu dasar masih lebih rendah dibandingkan zeolit-X yang disintesis dari bahan murni. Luas permukaan zeolit-X dari abu dasar adalah $250,850 \mathrm{~m}^{2} / \mathrm{g}$, sedangkan zeolit-X dari bahan murni sebesar 472,471 $\mathrm{m}^{2} / \mathrm{g}$. Hasil uji kapasitas adsorpsi zeolit-X dari abu dasar untuk metilen biru dan kongo merah adalah 131,6973 mg/g dan 38,12684 mg/g, berturut-turut. Proses adsorpsi mengikuti persamaan isothermal Langmuir dengan mengikuti model kinetika adsorpsi orde kedua semu. Studi termodinamika mengindikasikan bahwa proses adsorpsi terjadi secara eksoterm dan bersifat spontan pada masing-masing temperatur.
\end{abstract}

Kata Kunci: Abu Dasar, Zeolit-X, Adsorpsi, Metilen Biru, Kongo Merah

\section{Pendahuluan}

Pewarna diproduksi lebih dari $7 \times 10^{5}$ ton per tahun untuk digunakan dalam berbagai industri antara lain industri tekstil. 10-15\% pewarna ini dibuang ke lingkungan dalam bentuk limbah (Almeida, dkk., 2009). Diantara pewarna tekstil yang banyak digunakan adalah metilen biru dan kongo merah yang merupakan jenis zat warna kationik dan anionik (Derakhshan dkk., 2013). Kehadiran pewarna sebagai limbah ini sangat mengganggu estetika dan lingkungan. Produk pewarna dan degradasinya beracun dan bahkan karsinogenik, sehingga sangat berbahaya bagi manusia dan organisme di lingkungannya (Azizi dkk., 2014). Oleh karena itu, pengolahan limbah pewarna memerlukan perhatian serius. 
Beberapa teknologi telah digunakan untuk penghilangan zat warna seperti koagulasi, oksidasi kimia, pemisahan membran, proses elektrokimia dan teknik adsorpsi. Dari banyak contoh diatas adsorpsi fisik menggunakan adsorben padat merupakan salah satu metode yang menjanjikan untuk mengolah air limbah, karena keuntungannya seperti kesederhanaan operasional, biaya rendah, ketersediaan dalam jumlah besar dan kemampuan untuk mengolah limbah polutan dalam operasi skala yang cukup besar (Ferrero dkk., 2007).

Salah satu alternatif material adsorben yang dapat digunakan adalah abu dasar, yang dihasilkan dari bawah tungku pembakaran (Jin dkk., 2008). Sekali proses pembakaran batubara dapat menghasilkan limbah abu dasar sebanyak 20\% dan dapat mencapai 5,8 ton/hari menurut data Kementerian Lingkungan Hidup tahun 2006. Limbah abu dasar ini dikategorikan sebagai limbah B3 (bahan beracun dan berbahaya) menurut Peraturan Pemerintah No. 85/1999. Pemanfaatan abu dasar yang berbahaya ini dapat dilakukan dengan cara mengkonversi abu dasar menjadi zeolit yang tidak berbahaya bagi lingkungan. Zeolit ini telah banyak dilaporkan digunakan sebagai material adsorben (Widiastuti dkk., 2011).

Zeolit merupakan deretan kristal berpori dengan susunan pori yang rumit dan kanal-kanal dengan ukuran antara 0,3 nm-1 nm, dan telah digunakan secara luas sebagai katalis, adsorben, dan penukar ion. Material zeolit memiliki sifat yang unggul seperti susunan struktur yang unik, ukuran pori yang seragam dan bersambung, memiliki luas permukaan yang tinggi, volume pori yang besar dan telah menunjukkan peningkatan yang signifikan dalam mengadsorp senyawa pewarna dibanding karbon aktif komersial (Jumaeri dkk., 2007). Beberapa zeolit yang disintesis dari limbah dan yang pernah dipakai untuk adsorbsi metilen biru dan kongo merah sebagai berikut TiO-N/Zeolit, surfactanant-modified zeolite, zeolit yang disintesis dari residu elektrolik (EMRZ), zeolit yang disintesis dari kaolin, zeolit alam dimodifikasi $\mathrm{N}$, zeolit-NaA, zeolit-A dan zeolit-X dari abu layang, dan komposit zeolit. Zeolite A telah dilaporkan memiliki kapasitas adsorpsi metilen biru sebesar $25,98 \mathrm{mg} / \mathrm{g}$, sedangkan zeolit-X menunjukkan nilai yang lebih tinggi yakni $35,42 \mathrm{mg} / \mathrm{g}$ dari konsentrasi awal $70 \mathrm{mg} / \mathrm{L}$ (Wang dkk., 2016). Selain itu, zeolit- $X$ ini memiliki stabilitas termal yang tinggi, sehingga sesuai untuk mengadsorp limbah industri dengan suhu tertentu (Thanh dkk., 2018).

Tujuan penelitian ini adalah mengkonversi abu dasar menjadi zeolit-X yang selanjutnya digunakan sebagai adsorben untuk metilen biru dan kongo merah. Sintesis zeolit-X dilakukan dengan metode hidrotermal pada suhu $100^{\circ} \mathrm{C}$ selama 15 jam yang merupakan kondisi optimum berdasarkan penelitian Zhang dkk., (2013). Parameter yang diteliti dalam proses adsorpsi diantaranya adalah waktu kontak, pengaruh konsentrasi, dan suhu adsorpsi. Pada studi ini juga dilakukan penentuan kinetika adsorpsi, isoterm adsorpsi, dan parameter termodinamika adsorpsi agar diketahui secara komprehensif proses adsorpsi metilen biru dan kongo merah untuk skala besar.

\section{Metode Penelitian}

\subsection{Identifikasi Komposisi Kimia Fase Mineral dari Abu Dasar}

Sintesis zeolit-X dari abu dasar salah satu industri petrokimia, diawali dengan penentuan komposisi kimia dari abu dasar. Abu dasar yang diidentifikasi, terlebih dahulu diayak dengan ukuran 60 mesh untuk memperoleh partikel abu dasar yang seragam dan halus. Abu dasar yang halus ini kemudian di panaskan pada suhu $105^{\circ} \mathrm{C}$ selama 3 jam untuk menghilangkan kadar air. Setelah itu abu dasar halus yang sudah dipanaskan dimasukkan dalam desikator. Selanjutnya, abu dasar dianalisa menggunakan $X$ ray Flouresense (XRF) dan X-ray Diffraction (XRD) untuk menentukan komposisi unsur-unsur kimianya serta fasa mineral dari abu dasar.

\subsection{Pemisahan Fe Abu Dasar Batubara}

Pemisahan kandungan besi $(\mathrm{Fe})$ pada abu dasar batubara pada penelitian ini dilakukan menggunakan magnet ferrit. Mula-mula abu dasar diletakkan dalam bejana yang cukup luas, kemudian magnet ferrit diletakkan pada bagian atas abu dasar secara bergantian diseluruh permukaan bejana tersebut. Agar kandungan besi hilang secara merata, maka abu dasar diaduk secara terus menerus. 


\subsection{Pemisahan Ca Abu Dasar Batubara}

Pemisahan logam Ca pada abu dasar dilakukan menurut metode yang dilaporkan oleh Chareonpanic dkk (2011). Abu dasar bebas Fe ditimbang sebanyak 5 gram dan dimasukkan dalam larutan $\mathrm{HCl} 12 \mathrm{M}$ sebanyak $150 \mathrm{ml}$. Campuran tersebut kemudian diaduk secara terus menerus selama 4 jam pada suhu $100-110^{\circ} \mathrm{C}$ untuk memaksimalkan proses pemisahan. Setelah selesai campuran difiltrasi dan dikeringkan selama 1 jam dengan suhu $105^{\circ} \mathrm{C}$.

\subsection{Ekstraksi Si dan Al pada Abu Dasar melalui Peleburan dengan Atmosfer Udara}

Abu dasar bebas $\mathrm{Fe}$ dan Ca ditimbang sebanyak 10 gram, kemudian ditambahkan dengan padatan $\mathrm{NaOH}$ sebanyak 12 gram. $\mathrm{NaOH}$ dapat mengurangi sifat hidrofilik bahan sehingga meningkatkan kompatibilitas. Selain itu, $\mathrm{NaOH}$ dapat melarutkan kotoran (Laksono dkk., 2019). Campuran abu dasar dan $\mathrm{NaOH}$ diperamkan selama 30 menit dan dilanjutkan dengan reaksi selama 1 jam pada suhu $750{ }^{\circ} \mathrm{C}$ dalam furnace tanpa aliran gas. Padatan hasil fusi kemudian dimasukkan kedalam desikator dan ditimbang. Hasil padatan dilanjutkan dengan pengerusan, hingga didapat serbuk dengan ukuran lebih kecil. Padatan yang sudah ditimbang ditambahkan air dengan perbandingan 10 gram : $12 \mathrm{ml}$ air dan diaduk dengan kecepatan $500 \mathrm{rpm}$ selama 1 jam dan hasilnya kemudian disaring untuk diambil filtratnya.

\subsection{Sintesis Zeolit-X Bahan Murni}

Sintesis zeolit-X dalam penelitian ini dengan bahan murni (BM) dilakukan dengan perbandingan komposisi 4.0 $\mathrm{Na}_{2} \mathrm{O}: 0.2 \mathrm{Al}_{2} \mathrm{O}_{3}: 1.0 \mathrm{SiO}_{2}: 200 \mathrm{H}_{2} \mathrm{O}$ (Yanti Y, 2009). Pertama, $\mathrm{NaOH}$ ditimbang sebanyak 10,3511 gram dan dilarutkan dalam aqua demineralisasi. Larutan $\mathrm{NaOH}$ yang terbentuk dibagi menjadi dua bagian (A dan B) dalam gelas polipropilena yang berbeda. Larutan $\mathrm{NaOH}$ A dicampur dengan padatan $\mathrm{NaAlO}_{2}$, sedangkan $\mathrm{NaOH}$ B dicampur dengan $\mathrm{NaSiO}_{3}$. Kedua larutan tersebut diaduk secara terpisah dengan kecepatan konstan selama kurang lebih 15 menit, dan selanjutnya kedua sampel itu dicampur dan diaduk selama 3 jam.

Tahapan selanjutnya adalah larutan prekursor zeolit-X dimasukkan dalam reaktor hidrotermal (stainless steel autoclave) selama 24 jam pada suhu $100^{\circ} \mathrm{C}$. Padatan disaring dan dicuci dengan air demineralisasi berulang kali hingga $\mathrm{pH}$ filtratnya mencapai sekitar 8 . Setelah itu, padatan hasil sintesis dikeringkan dalam oven pada suhu $105^{\circ} \mathrm{C}$ selama 15 menit, diikuti dengan pendinginan dalam desikator hingga mencapai suhu kamar.

\subsection{Sintesis Zeolit-X dari Abu Dasar}

Sintesis zeolit-X dari abu dasar (AD) ini mengikuti penelitian yang pernah dilakukan oleh Yanti (2009). Awalnya, dilakukan extraksi Si dan Al yang terkandung dalam abu dasar. Extrak tersebut kemudian dibuat slurry dengan komposisi molar $\mathrm{NaAlO}_{2}: 4 \mathrm{SiO}_{2}: 16 \mathrm{NaOH}: 128 \mathrm{H}_{2} \mathrm{O}$. Penambahan $\mathrm{NaAlO}_{2}$ sebagai sumber $\mathrm{Al}$ digunakan untuk mengatur rasio molar $\mathrm{Si} / \mathrm{Al}$ yang sesuai untuk sintesis zeolit $\mathrm{Na}-\mathrm{X}$. Selanjutnya campuran slurry dimasukkan kedalam autoklaf stainless steel yang tertutup rapat untuk kristalisasi hidrotermal, padatan hasil kristalisasi dipisahkan dari filtratnya. Kemudian padatan yang sudah didapatkan dilakukan pengukuran $\mathrm{pH}$, pencucian ini dilakukan hingga mencapai $\mathrm{pH} 8$.

\subsection{Penentuan kinetika Adsorbsi}

Pengaruh variasi kontak dilakukan untuk mengetahui waktu optimum proses adsorpsi pada material zeolit-X bahan sintetik maupun bahan alam. Proses adsorpsi kedua zat warna baik metilen biru dan kongo merah dilakukan dalam botol duran tertutup dengan dosis adsorben $20 \mathrm{mg} / 20 \mathrm{~mL}$ dan konsentrasi awal adsorbat sebesar $50 \mathrm{mg} / \mathrm{L}$. Variasi waktu kontak dilakukan setiap 5 menit. Waktu yang digunakan $5,10,15,20,25,30$ menit dan seterusnya hingga setimbang. Setelah proses adsorpsi dalam waktu yang telah ditentukan, larutan disentrifugasi dengan kecepatan 3.500 rpm selama 10 menit untuk memisahkan adsorben dengan adsorbat. Konsentrasi dari larutan kemudian diukur menggunakan spektrofotometer UV-Vis.

Lima model kinetik yang digunakan untuk menentukan proses adsorpsi pada penelitian ini adalah orde satu semu, orde dua semu, Bungham, difusi intra partikel dan Elovich. Pertama, orde satu semu adalah 
persamaan yang bisa digunakan untuk menggambarkan adsorpsi dan ditentukan oleh Persamaan 1 (Ho dkk., 2009).

$$
\frac{d q}{d t}=k_{1}\left(q_{e}-q_{t}\right)
$$

dengan $q_{e}$ merupakan kapasitas adsorpsi pada keseimbangan (mg/g), $q_{t}$ merupakan kapasitas adsorpsi pada waktu $\mathrm{t}(\mathrm{mg} / \mathrm{g})$ dan $k_{1}$ merupakan konstanta kecepatan adsorpsi orde satu semu (1/menit). Persamaan tersebut kemudian dilakukan integral dengan batas $t=0$ hingga $t=t$ dan $q=0$ hingga $q=t$, sehingga didapatkan Persamaan 2.

$$
\ln \left(q_{e}-q_{t}\right)=\operatorname{Ln} q_{e}-k_{1} t
$$

Model kinetika orde dua semu menunjukkan bagaimana adsorbat tergantung pada kapasitas penyerapan dari adsorben bukan pada konsentrasi adsorbat. Model kinetika orde dua semu ditunjukkan pada Persamaan 3.

$$
\frac{d q_{t}}{d t}=k_{2}\left(q_{e}-q_{t}\right)^{2}
$$

dimana $k_{2}$ adalah konstanta kecepatan adsorpsi orde dua semu (g/mg.menit). Pengintegrasian dilakukan dengan kondisi batas $\mathrm{t}=0$ hingga $\mathrm{t}=\mathrm{t}$ dan $\mathrm{q}=0$ hingga $\mathrm{q}=\mathrm{t}$ sehingga didapatkan Persamaan 4 .

$$
\frac{t}{q_{t}}=\frac{1}{k_{2} q^{2} t}+\frac{t}{q_{e}}
$$

Laju serapan awal, $h(\mathrm{mg} / \mathrm{g}$ min $)$ sebagai $\mathrm{t} \rightarrow 0$ dapat didefinisikan seperti pada Persamaan 5.

$$
h=k_{2} q^{2} t
$$

tingkat adsorpsi awal (h), kapasitas adsorpsi $q_{e}$ dan konstanta orde dua semu dapat ditentukan secara percobaan dari kemiringan dan intersep antara plot $t / q_{t}$ dengan $t$.

Menurut Bungham (1979) persamaan model kinetik ini digunakan untuk mempelajari tahap-tahap pada adsorpsi yang telah berlangsung. Laju adsorpsi awal $(\alpha)$ dan konstanta laju Bangham $\left(\mathrm{k}_{\mathrm{o}}\right)$ dapat ditentukan secara eksperimen dari slope dan intersep plot dari $\log \left(\log \mathrm{C}_{\mathrm{o}} / \mathrm{C}_{\mathrm{o}}-\mathrm{q}_{\mathrm{t}} \cdot \mathrm{m}\right)$ versus $\log \mathrm{t}$, yang ditunjukkan pada Persamaan 6.

$$
\log \log \left[\frac{C_{o}}{C_{o}-q_{t} m}\right]=\log \left[\frac{k_{o} m}{2.303 \mathrm{~V}}\right]+\propto \log t
$$

dimana $\mathrm{C}_{\mathrm{o}}$ merupakan konsentrasi awal adsorbat dalam larutan $(\mathrm{mg} / \mathrm{L}), V$ adalah volume larutan $(\mathrm{mL})$, $m$ adalah berat adsorben per liter larutan $(\mathrm{g} / \mathrm{L}), q_{t}(\mathrm{mg} / \mathrm{g})$ adalah jumlah adsorbat yang tertinggal pada waktu $t$, dan $\alpha(<1)$ dan $k_{o}$ adalah tetapan/konstanta (Chen dkk., 2009).

Studi difusi intra partikel juga digunakan dalam studi kinetik ini. Rumus model intra-partikel dinyatakan sebagai Persamaan 7.

$$
q_{t}=k_{i d} t^{1 / 2}+C
$$

dimana $K_{i d}$ adalah konstanta laju difusi intra-partikel. Sebuah plot $q_{t}$ versus $t^{1 / 2}$ akan didapatkan garis lurus dengan slope $K_{i d}{ }^{-}$dan intersep C ketika mekanisme adsorpsi mengikuti proses difusi intrapartikel. Nilai intersep menandakan ketebalan dari batas lapisan (Chen dkk., 2009).

Persamaan Elovich (Thomas \& Thomas 1997) berasumsi bahwa permukaan padat sesungguhnya adalah sepenuhnya homogen, terjadi proses adsorpsi kimia sehingga laju desorpsinya rendah. Persamaan Elovich dinyatakan pada Persamaan 8.

$$
\frac{d q_{t}}{d t}=\alpha e^{-\beta q t}
$$

Integrasi Persamaan 8 diatas dan pengunaan kondisi awal $q_{t}=0$ pada $t=0$ dan $q_{t}=q_{t}$ pada $t=t$, diperoleh model Elovich sesuai dengan Persamaan 9.

$$
q_{t}=\left(\frac{1}{\beta}\right) \ln (\alpha \beta)+\left(\frac{1}{\beta}\right) \ln t
$$

dimana $\alpha$ adalah laju adsorpsi awal (mg/(gmin) dan parameter $\beta$ berhubungan dengan luas permukaan yang tertutup dan energi aktifitas (g/mg) (Widiastuti dkk., 2011).

\subsection{Penentuan Isotherm Adsorpsi}

Studi isoterm adsorpsi zat warna metilen biru dan kongo merah menggunakan zeolite- $\mathrm{X}$ hasil sintesis dianalisis menggunakan persamaan isoterm adsorpsi Langmuir dan Freundlich. Data yang digunakan dalam penentuan kinetika adsorpsi adalah data yang berasal dari variasi konsentrasi adsorbat. Kesesuaian model kinetika adsorpsi pada masing-masing adsorbat dilihat dari kesesuaian data eksperimen dan nilai koefisien korelasi $\left(R^{2}\right)$. 
Persamaan isotermal adsorpsi Langmuir dituliskan pada Persamaan 10.

$$
\frac{1}{Q e}=\frac{1}{Q m}++\frac{1}{Q m x k l \times c e}
$$

dilakukan plot grafik antara $1 / \mathrm{C}_{\mathrm{e}}$ sebagai sumbu $\mathrm{x}$ dan $1 / \mathrm{Q}_{\mathrm{e}}$ sebagai sumbu $\mathrm{y}$, sehingga nilai $\mathrm{Q}_{\mathrm{m}}$ (Kapasitas adsorpsi maksimum) didapatkan dari 1/intersept dan nilai kl (konstanta Langmuir) didapatkan dari intersept/slope.

Persamaan isoterm adsorpsi Freunlich dapat dilihat pada Persamaan 11.

$$
\text { Ln } Q e=\operatorname{Lnk}_{f}+\frac{1}{n} \operatorname{Ln} C_{e}
$$

Dengan melakukan plot grafik antara $\ln \mathrm{C}_{\mathrm{e}}$ sebagai sumbu $\mathrm{x}$ dan $\ln \mathrm{Q}_{\mathrm{e}}$ sebagai sumbu y, sehingga nilai kf (Konstanta Freundlich) didapatkan dari 2,303 log intersept.

Persamaan isotherm adsorpsi Temkin dapat dilihat pada Persamaan 12.

$$
Q e=\beta \operatorname{Ln} K_{T}+\beta \operatorname{Ln} C_{e}
$$

dimana nilai $\beta$ sebanding dengan RT/b. R merupakan konstanta gas universal dengan nilai $8,314 \mathrm{~kJ} / \mathrm{mol}$, $\mathrm{T}$ merupakan suhu dengan satuan Kelvin, sedangkan b merupakan variasi energi adsorpsi (Munagapati dkk., 2017).

\subsection{Penentuan Termodinamika Adsorbsi}

Parameter termodinamik dari proses adsorpsi yaitu $\Delta G^{\circ}, \Delta H^{\circ}$ dan $\Delta S^{\circ}$. Penghitungan energi bebas Gibbs $\left(\Delta \mathrm{G}^{\circ}\right)$ dari proses adsorpsi dapat dilakukan menggunakan Persamaan 13 (Chabani dkk., 2006).

$$
\Delta G^{\circ}=-R T \ln K d
$$

dimana $\mathrm{K}$ adalah konstanta kesetimbangan.

Persamaan yang menyatakan ketergantungan suhu dari energi adsorpsi dapat dilihat pada Persamaan 14.

$$
d\left(\frac{\Delta G^{0}}{T}\right)=\left(\frac{\Delta H^{0}}{T^{2}}\right) d t
$$

disubtitusikan menjadi Persamaan 15.

$$
\frac{d \ln K}{d\left(\frac{1}{T}\right)}=\frac{-\Delta H^{0}}{R T^{2}}
$$

Ini mengasumsikan bahwa $\Delta \mathrm{H}^{\circ}$ kira-kira independen dari suhu, kemiringan $\ln \mathrm{K}$ versus $1 / \mathrm{T}$ plot menghasilkan $\Delta \mathrm{H}^{\circ}$. Jika prosesnya adalah endotermik $(\Delta \mathrm{H}>0)$, konstanta kesetimbangan meningkat dengan suhu, sedangkan jika prosesnya eksotermik $\left(\Delta \mathrm{H}^{\circ}<0\right)$, konstanta kesetimbangan menurun ketika suhu dinaikkan. Perubahan entropi adsorpsi dapat ditentukan dengan Persamaan 16.

$$
\Delta G^{0}=-\Delta H^{0}-T \Delta S^{0}
$$

\section{Analisis dan Pembahasan}

\subsection{Preparasi Si dan Al dari Abu Dasar}

Penelitian ini dimulai dengan menentukan komposisi kimia abu dasar. Pada sintesis zeolit- $X$ dari abu dasar, sangat penting untuk diketahui prosentase kandungan mineral-mineral dalam abu dasar. Pada penelitian ini, hasil analisa abu dasar dengan X-Ray Flourescence (XRF) ditunjukkan pada Tabel 1. Berdasarkan analisa XRF didapatkan rasio Si/Al sebesar 2,3. Komponen selain Si dan Al, yang dominan dalam abu dasar adalah $\mathrm{Ca}$ dan $\mathrm{Fe}$. Kandungan $\mathrm{Fe}$ dan $\mathrm{Ca}$ yang tinggi dapat menggangu pembentukan zeolit, sehingga logam $\mathrm{Ca}$ dan $\mathrm{Fe}$ harus dipisahkan terlebih dahulu sebelum digunakan untuk sintesis zeolit. 
Tabel 1: Hasil Analisa Komposisi Kimia Abu Dasar

\begin{tabular}{cccc}
\hline Komponen & (\% berat $)$ & Komponen & $(\%$ berat $)$ \\
\hline $\mathbf{A l}$ & 9,9 & $\mathrm{Mn}$ & 0,23 \\
$\mathrm{Si}$ & 23 & $\mathrm{Fe}$ & 52,39 \\
$\mathrm{~S}$ & 1,1 & $\mathrm{Cu}$ & 0,17 \\
$\mathrm{~K}$ & 1,3 & $\mathrm{Zn}$ & 0,04 \\
$\mathrm{Ca}$ & 8,57 & $\mathrm{Rb}$ & 0,06 \\
$\mathrm{Ti}$ & 1,76 & $\mathrm{Sr}$ & 0,71 \\
$\mathrm{~V}$ & 0,058 & $\mathrm{Ba}$ & 0,2 \\
$\mathrm{Cr}$ & 0,054 & $\mathrm{Re}$ & 0,1 \\
$\mathrm{Zr}$ & 0,32 & $\mathrm{Na}$ & Tidak terukur
\end{tabular}

Penghilangan Fe dilakukan dengan magnet ferrit dan Ca dengan $\mathrm{HCl} 12 \mathrm{M}$. Abu dasar setelah dilakukan penghilangan $\mathrm{Fe}$ dan $\mathrm{Ca}$, dianalisa kembali untuk menentukan komposisi kimia. Hasil pada Tabel 2 menunjukkan bahwa penghilangan Fe dan Ca mampu menurunkan Fe sebesar 22,89\% dan Ca sebesar 4,36\%. Reaksi yang terjadi dapat dilihat pada Persamaan 17- Persamaan 19.

$$
\begin{array}{lll}
\mathrm{F}_{2} \mathrm{O}_{3(\mathrm{~s})}+\mathrm{HCl}_{(\mathrm{aq})} & \longrightarrow & 2 \mathrm{FeCl}_{3(\mathrm{aq})}+\mathrm{CO}_{2(\mathrm{~g})}+\mathrm{H}_{2} \mathrm{O}_{(\mathrm{l})} \\
\mathrm{CaO}_{(\mathrm{s})}+\mathrm{HCl}_{(\mathrm{aq})} & \longrightarrow & \mathrm{CaCl}_{2(\mathrm{aq})}+\mathrm{H}_{2} \mathrm{O}_{(\mathrm{l})} \\
\mathrm{CaCO}_{3(\mathrm{~s})}+2 \mathrm{HCl}_{(\mathrm{aq})} & \longrightarrow & \mathrm{CaCl}_{2(\mathrm{aq})}+\mathrm{CO}_{2(\mathrm{~g})}+\mathrm{H}_{2} \mathrm{O}_{(\mathrm{l})}
\end{array}
$$

Fase mineral dari abu dasar sebelum dan setelah penghilangan $\mathrm{Fe}$ dan $\mathrm{Ca}$ dianalisa menggunakan instrumen XRD dengan sumber radiasi $\mathrm{Cu}$ Ka, yang dapat dilihat pada Gambar 1.

Tabel 2: Hasil Analisa Komposisi Kimia Setelah Penghilangan Fe dan Ca

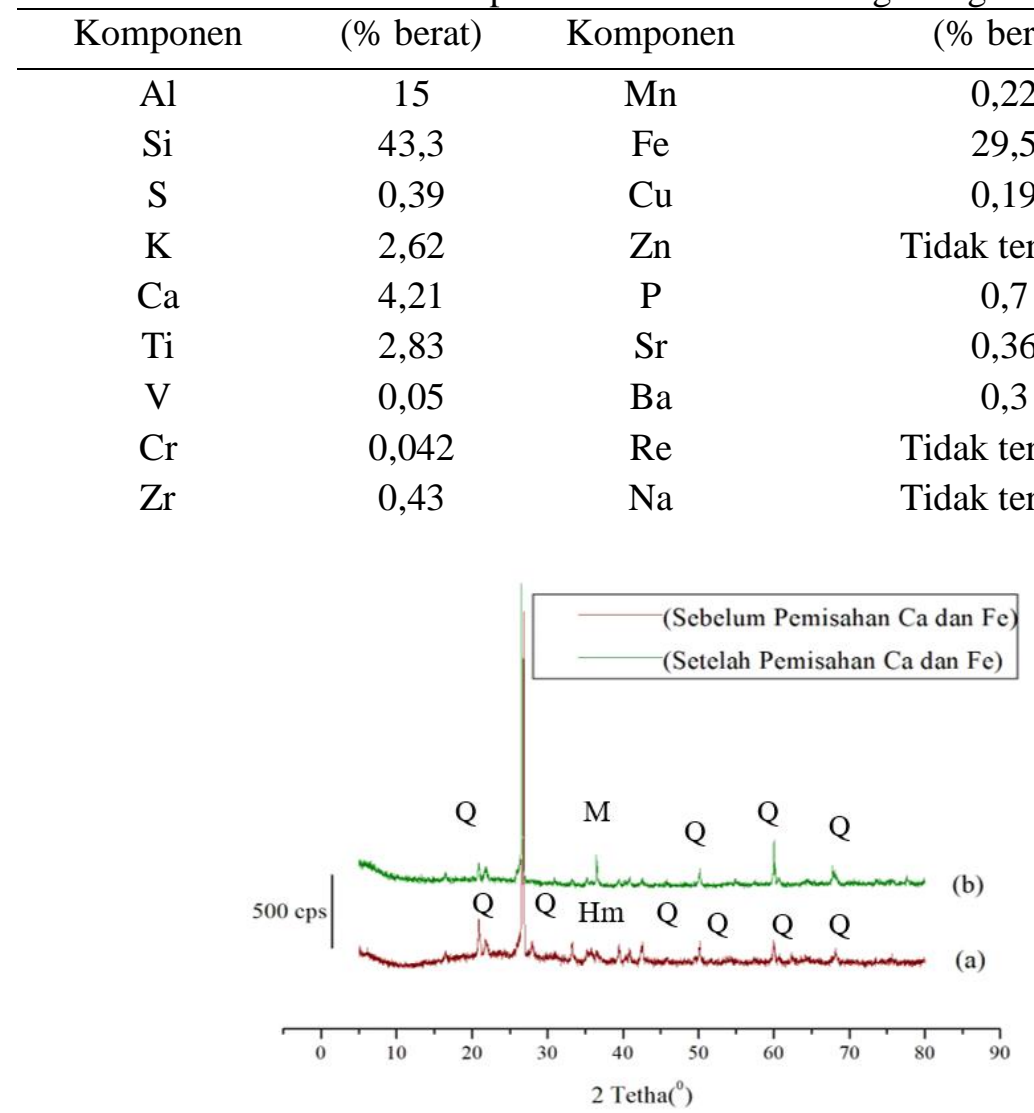

Gambar 1: Difraktogram Abu Dasar Sebelum Penghilangan dan Setelah Penghilangan Ca dan Fe

(Keterangan: Q=Quartz, $\mathrm{M}=$ Metal $(\mathrm{Fe}), \mathrm{Hm}=$ Hematite)

Komponen yang terdapat dalam abu dasar tersebut meliputi oksida-oksida dari silika dan besi yang berada dalam fasa kristalin meliputi mineral kuarsa $\left(\mathrm{SiO}_{2}\right)$ yang ditunjukkan oleh pola difraksi pada 
daerah $2 \theta=20,95^{\circ} ; 21,05^{\circ} ; 26,72^{\circ} ; 50,20^{\circ} ; 60,01^{\circ} ; 68,47^{\circ}$ (PDF 46-1045) dan Hematite $\left(\mathrm{Fe}_{2} \mathrm{O}_{3}\right)$ pada daerah $2 \theta=35,21^{\circ}$ (PDF 33-664). Pada Gambar 1, abu dasar merupakan fase amorf yang ditunjukkan oleh puncak pada daerah $2 \theta=20^{\circ}-40^{\circ}$. Fasa amorf memiliki peranan penting dalam pembuatan zeolit karena fasa amorf memiliki kelarutan yang tinggi dibandingkan dengan fasa kristalin dan kuarsa.

Abu dasar sebelum digunakan untuk sintesis zeolit-X, diekstraksi Si dan Al terlebih dahulu menggunakan metode peleburan yang dilaporkan oleh Yanti (2009). Peleburan ini menggunakan alkali $(\mathrm{NaOH})$ pada suhu tinggi yang bertujuan untuk mengaktifasi komponen utama Si dan Al pada abu dasar menjadi fasa mineral yang mudah larut, yaitu natrium silikat dan alumina silikat. Padatan hasil leburan abu dasar dalam atmosfer udara memiliki ciri fisik berwarna kuning kecoklatan yang menandakan bahwa kandungan karbon abu dasar telah hilang selama proses peleburan berlangsung.

Komponen mineral dalam abu dasar setelah proses peleburan juga dapat dianalisa menggunakan XRD yang hasilnya ditampilkan pada Gambar 2. Difraktogram tersebut menunjukkan hilangnya puncakpuncak hematit dan kalsit, karena proses peleburan pada suhu tinggi. Selain itu, puncak-puncak fasa kristalin lainnya seperti kuarsa dan mullit sebagian besar juga ikut menghilang. Selain fasa kristalin tersebut, fasa amorf dari aluminasilikat juga ditemukan dalam intensitas yang lebih banyak jika dibandingkan dengan abu dasar sebelum dilakukan peleburan.

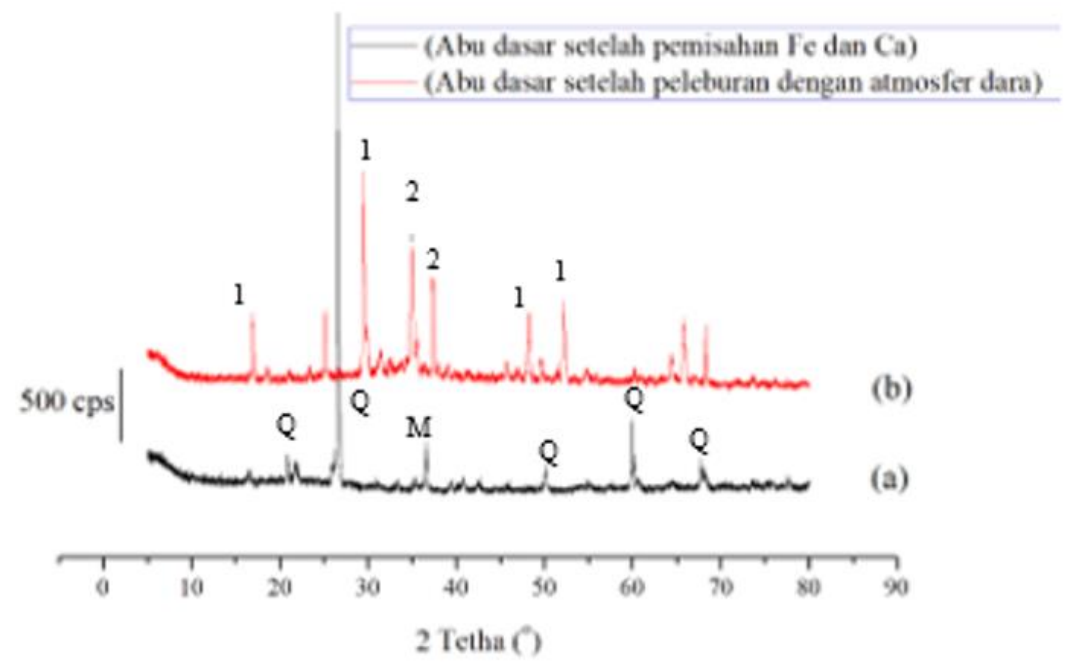

Gambar 2: Difraktogram Abu Dasar Setelah Pemisahan Fe dan Ca (a), Abu Dasar Setelah Peleburan Atmosfer Udara (b). (1= Natrium Silikat, 2= Natrium Aluminat Silikat, Q= Kuarsa, M=Mullit)

Tahap selanjutnya setelah didapatkan hasil berupa natrium silikat dan natrium aluminasilikat dari proses peleburan, kemudian dilakukan proses ekstraksi dari padatan hasil leburan untuk mendapatkan komponen Si dan Al yang terlarut. Pada proses ekstraksi ini dilakukan dengan mencampurkan hasil leburan dengan perbandingan 1 gram dalam $12 \mathrm{ml}$ air $(12 \mathrm{ml} / \mathrm{g})$. Hasil reaksi peleburan dengan air sesuai dengan Persamaan 20 dan Persamaan 21.

$$
\begin{aligned}
& \mathrm{Na}_{2} \mathrm{SiO}_{3(\mathrm{~s})}+\mathrm{H}_{2} \mathrm{O}_{(\mathrm{aq})} \rightarrow \mathrm{Na}_{2} \mathrm{SiO}_{3(\mathrm{aq})} \\
& \mathrm{Na}_{2} \mathrm{AlSiO}_{4(\mathrm{~s})}+\mathrm{H}_{2} \mathrm{O}_{(\mathrm{aq})} \rightarrow \mathrm{Na}_{2} \mathrm{Al}(\mathrm{OH})_{4(\mathrm{aq})}
\end{aligned}
$$

Setelah dilakukan pengeraman, filtrat yang didapatkan kemudian diuji menggunakan Inductively Coupled Plasma Atomic Spectroscopy (ICP-AES) untuk mendapatkan kadar Si, Al dan Na yang terkandung pada filtrat. Hasil analisa kandungan $\mathrm{Si}, \mathrm{Al}$, dan Na menggunakan ICP-AES didapatkan masing-masing dari komponen sebesar: $\mathrm{Si}=8,533 \mathrm{ppm}, \mathrm{Al}=0,154$ dan $\mathrm{Na}=16,941 \mathrm{ppm}$. Ekstrak tersebut kemudian digunakan sebagai bahan pembuatan gel.

\subsection{Sintesis Zeolit-X dari Abu Dasar}

Sintesis zeolit-X dari abu dasar dilakukan dengan komposisi molar $\mathrm{NaAlO}_{2}: 4 \mathrm{SiO}_{2}: 16 \mathrm{NaOH}: 128$ $\mathrm{H}_{2} \mathrm{O}$. Rasio ini berdasarkan pada penelitian yang dilaporkan oleh Yanti (2009). Gambar 3 menunjukkan bahwa zeolit-X terbentuk pada suhu kristalisasi $100^{\circ} \mathrm{C}$ selama 15 jam. Dari difraktogram tersebut 
menunjukkan bahwa zeolit yang terbentuk merupakan campuran dari zeolit-X, zeolit-A dan Sodalit. Hal ini ditandai dengan munculnya pucak-puncak spesifik pada zeolit-A, zeolit-X dan sodalit. Berdasarkan PDF 39-0222 puncak spesifik zeolit-A muncul pada sudut 20:7,18;10,16;12,46;16,10;29,94 dan seterusnya, sedangkan berdasarkan PDF NO. 12-0246, puncak spesifik zeolit-X berada pada sudut $2 \theta$ 6,$09 ; 10,0 ; 11,7 ; 15,44 ; 18,45 ; 20,09 ;$ dan seterusnya.

Pembuktian analisis XRD pada Gambar 3 dikonfirmasi dengan analisa menggunakan Scanning Electron Microscope (SEM) yang menunjukkan kristal zeolit-X (Gambar 4). Pada Gambar 4 terlihat masih ada zeolit-A yang berbentuk kubus dan sodalit, selain zeolit-X yang diharapkan (berbentuk oktahedral).

\subsubsection{Karakteristik Pori Zeolit-X}

Reaksi adsorpsi pada zeolit umumnya memanfaatkan rongga pori zeolit untuk menyimpan adsorbat. Oleh karena itu, perlu dilakukan penentuan luas permukaan dan struktur pori seperti volume pori dan distribusi ukuran pori. Zeolit memiliki luas permukaan tinggi. Berdasarkan pembahasan diatas, zeolit$\mathrm{X}$ dari bahan sintetik maupun zeolit-X dari abu dasar sangat potensial digunakan untuk adsorben zat warna (Du dkk., 2007). Zeolit memiliki luas permukaan yang tinggi, selain itu, nilai kristalinitas zeolit$X$ juga tinggi. Hal itu dibuktikan dengan hasil analisis SEM dan XRD. Grafik adsorpsi-desorpsi N2 dapat dilihat pada Gambar 5.

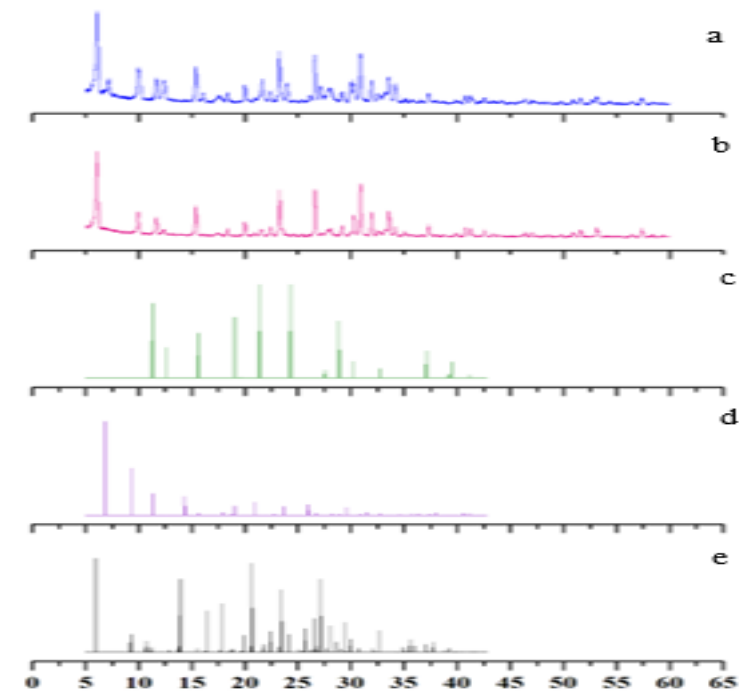

Gambar 3: Difraktogram Zeolit-X yang Disintesis dari Abu Dasar (a), Zeolit-X yang Disintesis dari Bahan Sintetik (B), Sodalit (C), Zeolit-A (D), dan Zeolit-X (e)

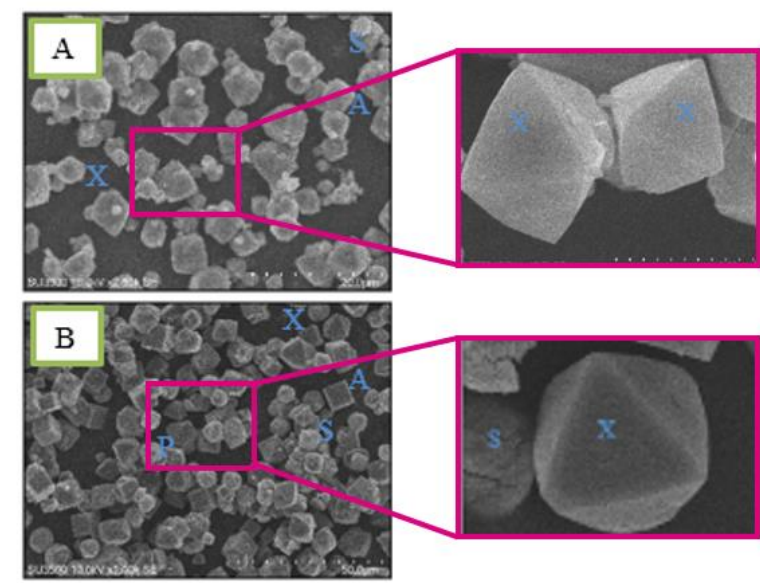

Gambar 4: Mikrograf SEM Zeolit-X yang Disintesis dari Bahan Sintetik (a) dan Mikrograf SEM Zeolit-X dari Abu Dasar (b) 


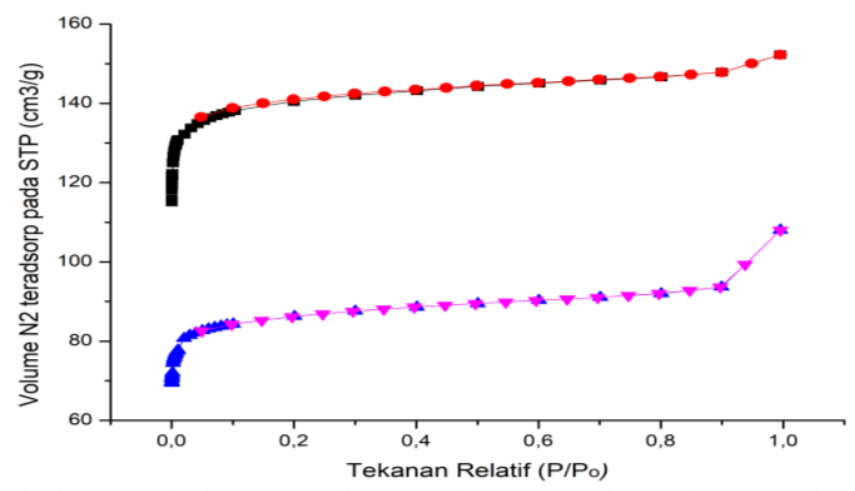

Gambar 5: Grafik Adsorbsi-Desorbsi $\mathrm{N}_{2}$ Zeolit-X Bahan Murni (a) dan Zeolit-X Bahan Abu Dasar (b)

\subsection{Hasil Adsorpsi Zat Warna}

\subsubsection{Penentuan Variasi Waktu Kontak}

Adsorben dan adsorbat yang digunakan yaitu $20 \mathrm{mg} / 20 \mathrm{~mL}$ dan konsentrasi awal yang digunakan dalam penentuan waktu adalah sebesar $50 \mathrm{mg} / \mathrm{L}$ pada $\mathrm{pH}$ 6-8 dan suhu ruang. Plot variasi waktu kontak dapat dilihat pada Gambar 6. Pada penelitian ini, kinetika adsorpsi dibahas untuk menentukan kecepatan adsorpsi setiap zat warna. Model Kinetika yang digunakan untuk mencocokkan data eksperimen dalam penelitian ini terdiri atas model orde satu semu, orde dua semu, Bangham, Difusi Intra Partikel, dan Elovich.

Model kinetika dipakai untuk menjelaskan mekanisme adsorpsi, yang tergantung pada karakteristik fisika atau kimia dari adsorben seperti halnya proses transfer massa. Model kinetika dapat diperoleh dalam penentuan waktu optimum yang dapat dilihat pada Gambar 6. Absorpsi kongo merah menggunakan zeolit-X dari bahan murni dan zeolit-X dari abu dasar ditunjukkan dengan nilai koefisien korelasi $\left(\mathrm{R}^{2}\right)$. Orde satu semu memiliki nilai yang lebih tinggi dibandingkan dengan plot orde dua semu.

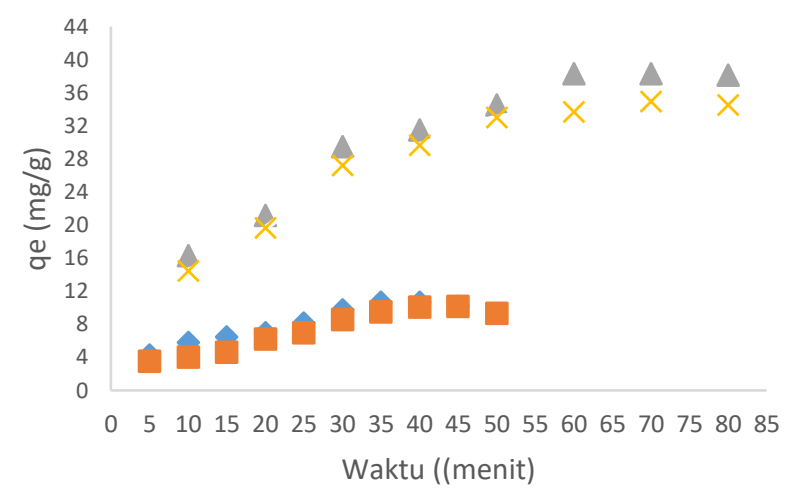

Gambar 6: Plot Variasi Waktu dan Kapasitas Adsorpsi Metilen Biru pada Zeolit-X dari Bahan Murni $(\boldsymbol{\Delta})$, Zeolit-X dari Abu Dasar $(X)$ dan Kongo Merah pada Zeolit-X dari Bahan Murni $(\diamond)$, Zeolit$\mathrm{X}$ dari Abu Dasar

Model kinetika yang digunakan untuk mencocokkan data eksperimen dalam penelitian ini terdiri atas model orde satu semu, orde dua semu, model Elovich, Model Bangham dan model difusi intra partikel. Model kinetika dipakai untuk menjelaskan mekanisme dari adsorpsi, yang tergantung pada karakteristik fisika atau kimia dari adsorben seperti halnya proses transfer massa. Model kinetika dapat diperoleh dalam penentuan waktu optimum yang dapat dilihat pada Gambar 7.

Pada Tabel 3 dapat diketahui bahwa adsorpsi kongo merah menggunakan zeolit-X dari bahan murni serta zeolit-X dari abu dasar masing masing adsorben menunjukkan bahwa nilai koefisien korelasi $\left(\mathrm{R}^{2}\right)$ orde satu semu memiliki nilai yang lebih tinggi dibandingkan dengan plot orde dua semu, Bangham, difusi intra partikel, dan Elovich untuk zat warna kongo merah, sedangkan pada zeolit-X yang disintesis dari abu dasar, nilai koefisien korelasi $\left(\mathrm{R}^{2}\right)$ orde dua semu lebih tinggi dibandingkan dengan nilai dari 
orde satu semu, Elovich, distribusi intra partikel dan Bangham. Nilai koefisien korelasi $\left(\mathrm{R}^{2}\right)$ yang lebih tinggi menunjukkan kesesuaian kinetika adsorpsi pada sistem tersebut.

Pada Tabel 4 dapat diketahui bahwa adsorpsi metilen biru menggunakan zeolit-X dari bahan murni serta zeolit-X dari abu dasar masing-masing adsorben menunjukkan bahwa nilai koefisien korelasi $\left(\mathrm{R}^{2}\right)$ orde satu semu memiliki nilai yang lebih tinggi dibandingkan dengan plot orde dua semu, Bangham, difusi intra partikel, dan Elovich untuk zat warna kongo merah. Nilai koefisien korelasi $\left(\mathrm{R}^{2}\right)$ yang lebih tinggi menunjukkan kesesuaian kinetika adsorpsi pada sistem tersebut. Nilai dari koefisien korelasi dari masing-masing plot dapat dilihat pada Tabel 4. Dari Tabel 4 dapat disimpukan kinetika adsorbsi masingmasing adsorben menunjukkan orde satu untuk semua jenis zeolit. Hal ini mengindikasikan bahwa adsorpsi metilen biru menggunakan adsorben zeolit-X bahan murni dan zeolit- $\mathrm{X}$ abu dasar terjadi secara kimia.

(a)

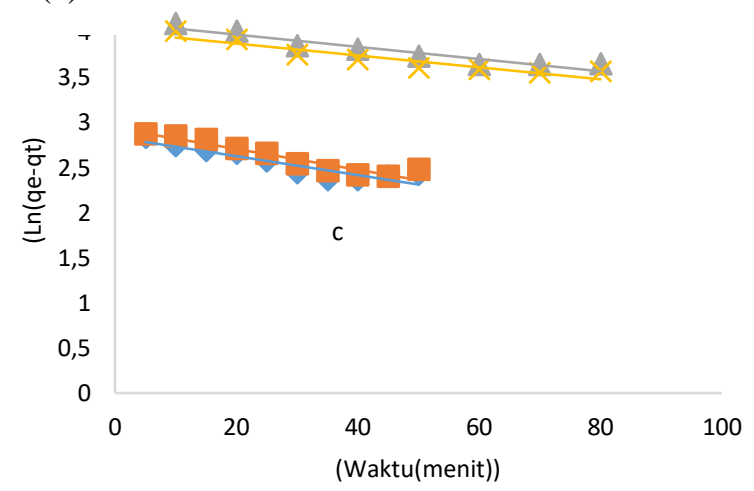

(c)

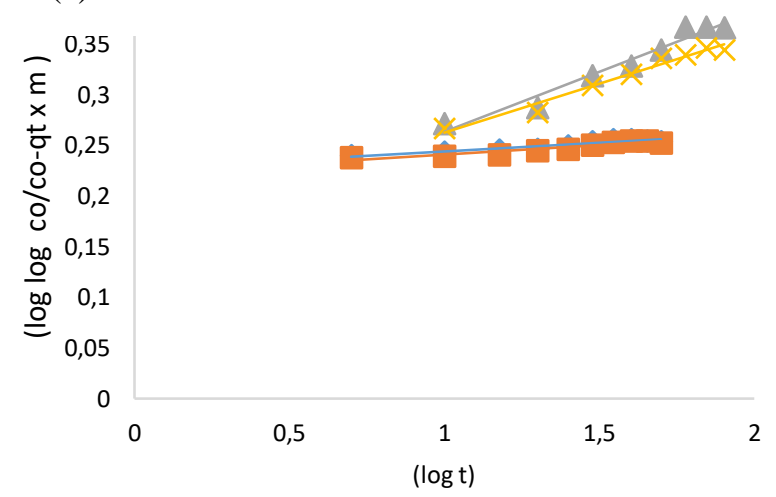

(b)

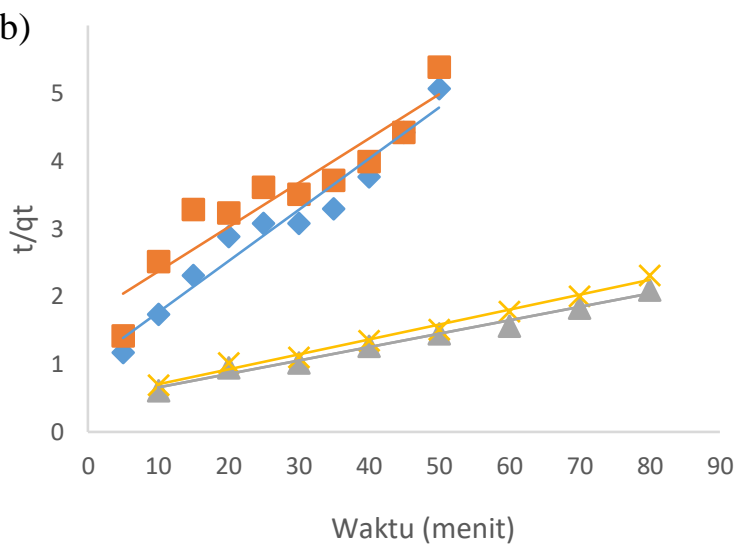

(d)

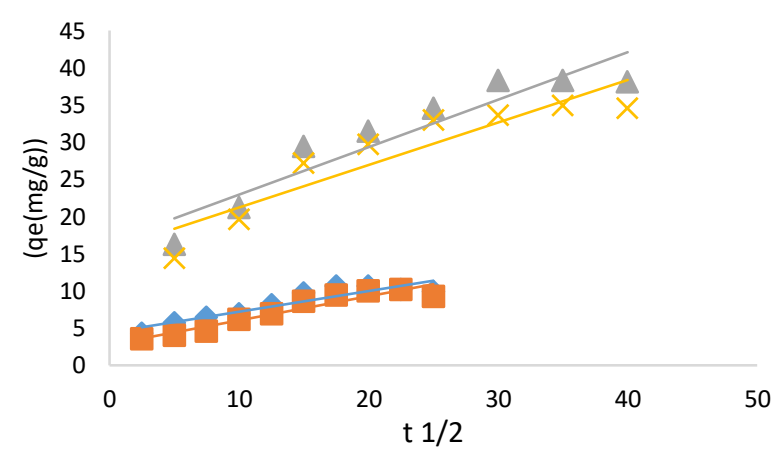

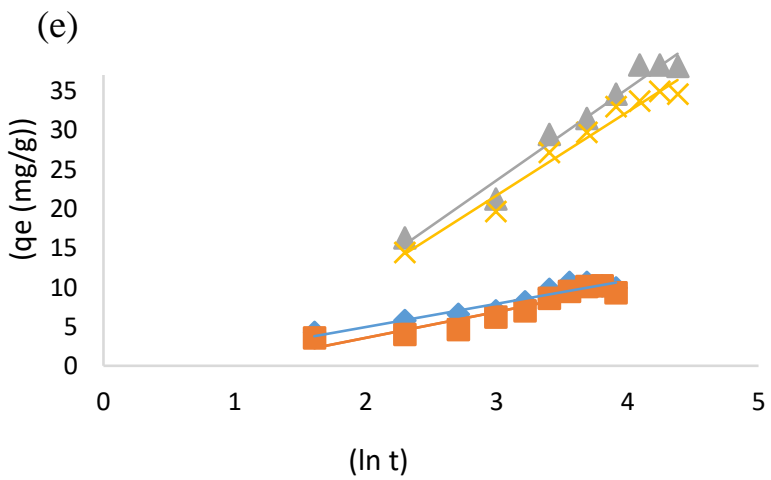

Gambar 7: Model Kinetik Orde Satu Semu (a), Orde Dua Semu (b), Bungham (c), Difusi Intra Partikel (d), dan Elovich (e). Kondisi Proses: Jumlah Adsorben 20 mg, Volume 20 ml, Konsentrasi Awal 50 ppm, Suhu Ruang dengan pH 6-8, untuk Metilen Biru pada Zeolit-X dari Bahan Murni ( $\mathbf{\Delta})$, Zeolit-X 
dari Abu Dasar (X) dan Kongo Merah pada Zeolit-X dari Bahan Murni Zeolit-X dari Abu Dasar (

Tabel 3: Ringkasan dan Perhitungan Kinetika Adsorpsi Kongo Merah

\begin{tabular}{|c|c|c|c|c|}
\hline Model Kinetika & Adsorben & & Parameter & \\
\hline \multirow[t]{3}{*}{ Orde satu semu } & Zeolit-X BM & $K f\left(\min ^{-1}\right)$ & Qe (mg/g) & $\mathbf{R}^{2}$ \\
\hline & & $-0,076$ & 2,741 & 0,955 \\
\hline & Zeolit-X AD & $-0,065$ & 5,551 & 0,869 \\
\hline \multirow[t]{3}{*}{ Orde dua semu } & Zeolit-X BM & $h(\mathrm{mg} / \mathrm{g} \mathrm{min})$ & Qe (mg/g) & $\mathbf{R}^{2}$ \\
\hline & & 0,352 & $-95,240$ & 0,811 \\
\hline & Zeolit-X AD & 0,340 & $-86,956$ & 0,9061 \\
\hline \multirow[t]{3}{*}{ Bangham } & Zeolit-X BM & $k_{o}(\mathrm{~mL} / \mathrm{g} \min )$ & $\alpha$ & $\mathbf{R}^{2}$ \\
\hline & & 3,881 & 0,017 & 0,903 \\
\hline & Zeolit-X AD & 3,838 & 0,018 & 0,881 \\
\hline \multirow[t]{3}{*}{ Elovich } & Zeolit-X BM & $\alpha(\mathrm{mg} /(\mathrm{gmin}))$ & $\mathrm{B}$ (g/mg) & $\mathbf{R}^{2}$ \\
\hline & & 2,114 & 0,337 & 0,855 \\
\hline & Zeolit-X AD & 1,309 & 0,302 & 0,906 \\
\hline \multirow[t]{3}{*}{ Difusi Intra Partikel } & Zeolit-X BM & $\mathbf{K}_{\mathbf{i d}}$ & C & $\mathbf{R}^{2}$ \\
\hline & & 0,778 & 4,419 & 0,909 \\
\hline & Zeolit-X AD & 0,324 & 2,797 & 0,886 \\
\hline
\end{tabular}

Tabel 4: Ringkasan dan Perhitungan Kinetika Adsorpsi Metilen Biru

\begin{tabular}{ccccc} 
Model Kinetika & Adsorben & & Parameter & \\
Orde satu semu & Zeolit-X BM & $\boldsymbol{K f}\left(\mathbf{m i n}^{-\mathbf{1}}\right)$ & $\mathbf{Q e}(\mathbf{m g} / \mathbf{g})$ & $\mathbf{R}^{\mathbf{2}}$ \\
\cline { 3 - 5 } & & $-0,019$ & 1,582 & 0,987 \\
Orde dua semu & Zeolit-X AD & $-0,022$ & 1,621 & 0,989 \\
& Zeolit-X BM & $\boldsymbol{h}(\mathbf{m g} / \mathbf{g} \mathbf{m i n})$ & $\mathbf{Q e}(\mathbf{m g} / \mathbf{g})$ & $\mathbf{R}^{\mathbf{2}}$ \\
& & 0,243 & $-147,06$ & 0,906 \\
Bangham & Zeolit-X AD & 0,25 & $-151,515$ & 0,878 \\
& Zeolit-X BM & $\boldsymbol{k}_{\boldsymbol{o}}(\mathbf{m} \mathbf{L} / \mathbf{g} \mathbf{m i n})$ & $\mathbf{a}$ & $\mathbf{R}^{\mathbf{2}}$ \\
& & 3,023 & 0,118 & 0,956 \\
Elovich & Zeolit-X AD & 3,374 & 0,096 & 0,972 \\
& Zeolit-X BM & $\boldsymbol{\alpha}(\mathbf{m g} /(\mathbf{g m i n}))$ & $\mathbf{B}(\mathbf{g} / \mathbf{m g})$ & $\mathbf{R}^{\mathbf{2}}$ \\
& & 4,391 & 0,856 & 0,881 \\
Difusi Intra & Zeolit-X AD & 4,062 & 0,094 & 0,848 \\
Partikel & Zeolit-X BM & $\mathbf{K}_{\text {id }}$ & $\mathbf{C}$ & $\mathbf{R}^{\mathbf{2}}$ \\
& & 0,638 & 16,565 & 0,971 \\
& Zeolit-X AD & 0,571 & 15,5 & 0,970
\end{tabular}

\subsubsection{Penentuan Isoterm Adsorpsi}

Adsorpsi dengan variasi konsentrasi awal adsorbat untuk mendapatkan kapasitas adsorpsi yang maksimum dari masing-masing adsorben. Penentuan konsentrasi bertujuan untuk menentukan karakteristik permukaan, afinitas adsorben dan kapasitas adsorpsi adsorben. Dalam penelitian ini, tiga isoterm diuji untuk menemukan korelasi yang paling tepat dari kurva equilibrium eksperimen.

Dari model variasi konsentrasi, dapat ditentukan model isoterm adsopsinya dan untuk mengetahui jenis adsorbsi yang terjadi. Setelah mengetahui jenis adsorbsi yang terjadi, maka dapat diketahui ikatan yang terjadi. Data ini sangat bermanfaat untuk mengetahui apakah adsorben yang digunakan dapat diregenerasi ulang atau tidak. Data isotherm dalam penelitian ini dianalisa dengan tiga model yaitu Langmuir, Freundlich dan Temkin. Hasil dapat dilihat pada Gambar 8. Nilai parameter adsorpsi isotherm dirangkum dalam Tabel 5 dan Tabel 6.

Pada Tabel 5, jika dilihat dari koefisien korelasi dari tabel tersebut, diketahui bahwa adsorbsi kongo merah menggunakan zeolit-X bahan murni lebih mengikuti model Freundlich dari pada model Langmuir dan Temkim, sedangkann untuk zeolit-X dari abu dasar cenderung mengikuti Langmuir dari pada 
Freundlich. Hal ini mengindikasikan adsorpsi yang terjadi pada zeolit-X bahan murni, terjadi secara monolayer, sedangkan pada zeolit- $X$ dari abu dasar lebih mengarah pada persamaan isoterm Langmuir. Hal ini mengindikasikan adsorpsi yang terjadi pada zeolit- $X$ dari abu dasar terjadi secara multilayer dan terjadi interaksi fisika antara adsorbat dan adsorben.

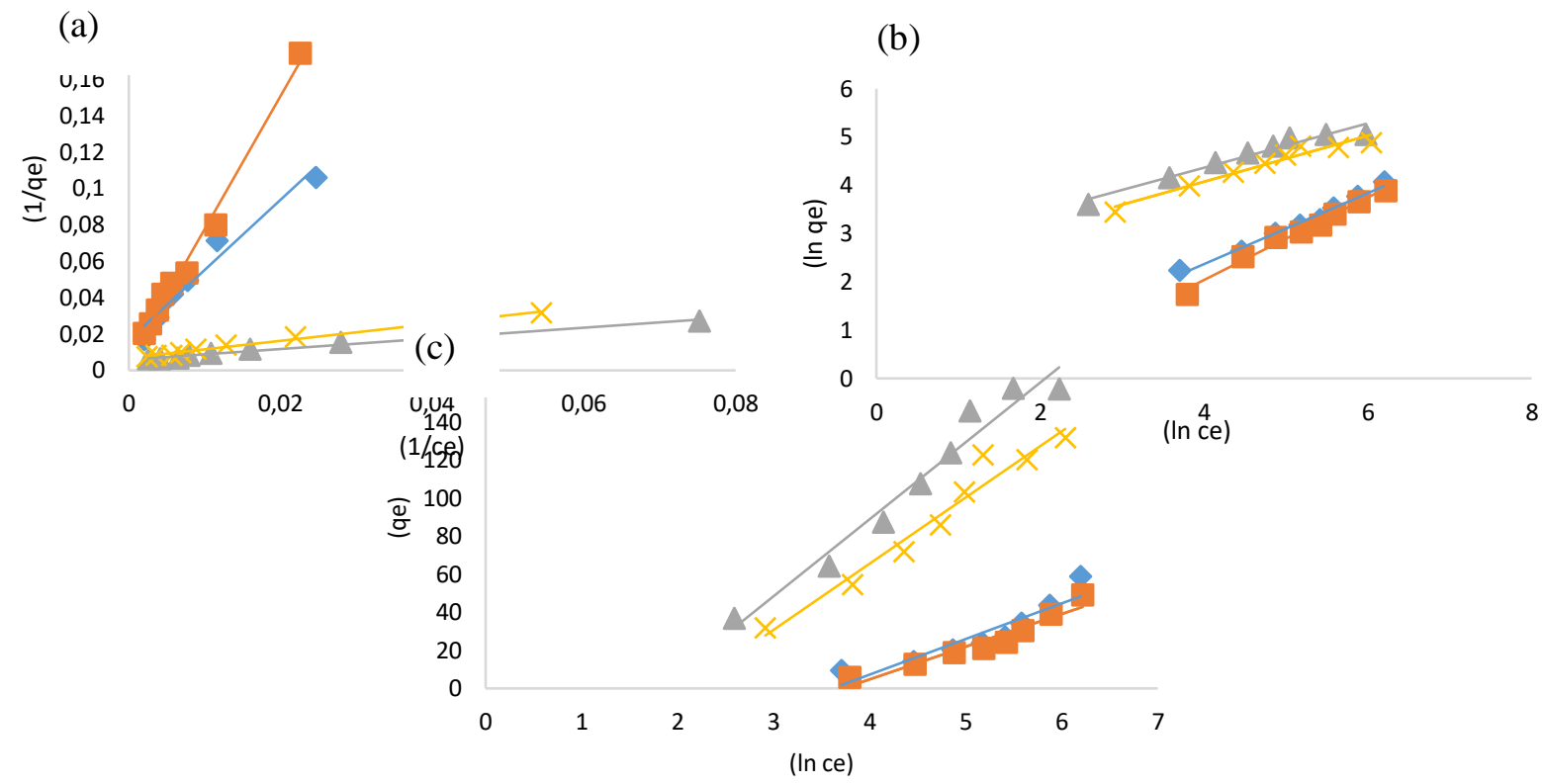

Gambar 8: Kurva Adsorpsi (a) Isoterm Langmuir, (b) Freundlich, dan (c) Temkin untuk Metilen Biru pada Zeolit-X dari Bahan Murni ( $\mathbf{\Delta})$, Zeolit-X dari Abu Dasar (X) dan Kongo Merah pada Zeolit-X dari Bahan Murni ( $\bullet)$, Zeolit-X dari Abu Dasar (

Tabel 5: Ringkasan dari Perhitungan Isoterm Adsorbsi Kongo Merah

\begin{tabular}{|c|c|c|c|c|}
\hline Model Isoterm & Adsorben & \multicolumn{3}{|c|}{ Parameter } \\
\hline \multirow{3}{*}{ Langmuir } & Zeolit-X BM & $\boldsymbol{K}$ & \multicolumn{2}{|c|}{$\mathbf{R}^{2}$} \\
\hline & & 232,39 & \multicolumn{2}{|c|}{0,9596} \\
\hline & Zeolit-X AD & 1625,04 & \multicolumn{2}{|c|}{0,9904} \\
\hline \multirow[t]{3}{*}{ Freundlich } & Zeolit-X BM & K & $1 / n$ & $\mathbf{R}^{2}$ \\
\hline & & 0,564 & 0,735 & 0,9852 \\
\hline & Zeolit-X AD & 0,25 & 0,856 & 0,9855 \\
\hline \multirow[t]{3}{*}{ Tempkin } & Zeolit-X BM & $\mathbf{K}$ & $\boldsymbol{B}$ & $\mathbf{R}^{2}$ \\
\hline & & 0,027 & 18,696 & 0,8584 \\
\hline & Zeolit-X AD & 0,024 & 17,161 & 0,9182 \\
\hline
\end{tabular}

Tabel 6 merupakan rangkuman dari isoterm yang terjadi pada metilen biru. Jika dilihat dari koefisien korelasi dari Tabel 6, diketahui bahwa adsorpsi metilen biru menggunakan zeolit-X bahan murni maupun abu dasar lebih mengikuti model Langmuir daripada model Freundlich dan Temkin. Hal ini mengindikasikan adsorbsi yang terjadi pada zeolit-X bahan murni, terjadi secara monolayer dan terjadi interaksi kimia antara adsorbat dan adsorben. Model adsorpsi isoterm Langmuir mengasumsikan bahwa seluruh sisi aktif adsorpsi memiliki afinitas yang sama. Selain itu proses adsorpsi pada satu sisi aktif tidak tergantung pada sisi aktif lainnya. Berdasarkan teori adsorpsi isoterm Langmuir, yang mengasumsikan bahwa adsorpsi terjadi pada permukaan spesifik dalam adsorben homogen (Langmuir, 1998). Selain itu, pada adsorpsi isotermal Langmuir, hanya terbentuk maksimum satu lapisan adsorpsi, masing-masing atom teradsorp hanya pada satu lokasi spesifik pada permukaan adsorben, dan masingmasing bagian dari permukaan adsorben hanya mengikat satu molekul atau atom. Adsorpsi isotherm tipe ini dapat digunakan untuk menentukan kapasitas adsorpsi tertinggi yang berkaitan dengan penutupan monolayer sempurna pada permukaan zeolit (Chabani dkk., 2006). 
Tabel 6: Ringkasan dari Perhitungan Isoterm Adsorpsi Metilen Biru

\begin{tabular}{ccccc}
\hline Model Isoterm & Adsorben & \multicolumn{3}{c}{ Parameter } \\
\hline Langmuir & Zeolit-X BM & $\boldsymbol{K}$ & \multicolumn{2}{c}{$\mathbf{R}^{\mathbf{2}}$} \\
& & 49,627 & \multicolumn{2}{c}{0,9858} \\
\multirow{3}{*}{ Freundlich } & Zeolit-X AD & 67,869 & \multicolumn{2}{c}{0,9876} \\
& Zeolit-X BM & $\boldsymbol{K}$ & $\mathbf{1 / n}$ & $\mathbf{R}^{\mathbf{2}}$ \\
& & 12,47 & 0,46 & 0,9516 \\
Tempkin & Zeolit-X AD & 8,738 & 0,477 & 0,9501 \\
& Zeolit-X BM & $\mathbf{K}$ & $\boldsymbol{B}$ & $\mathbf{R}^{\mathbf{2}}$ \\
& & 0,165 & 40,414 & 0,960 \\
& Zeolit-X AD & 0,121 & 34,744 & 0,955
\end{tabular}

Pada Gambar 9 terlihat hasil yang sama didapatkan pada adsorpsi zat warna metilen biru dan kongo merah, pada konsentrasi $300 \mathrm{mg} / \mathrm{L}$. Kapasitas adsorbsi pada grafik hampir konstan yang mengindikasikan adsorben hampir jenuh. Nilai kapasitas kongo merah cenderung rendah dibanding dengan metilen biru. Hal itu dikarenakan zeolit mempunyai muatan negatif, sehingga zeolit lebih banyak mengikat adsorbat yang bermuatan positif dari pada negatif, sehingga nilai kapasitas adsorbsi zeolit pada metilen biru lebih tinggi dibanding kongo merah. Selain itu, hal ini dikarenakan perbedaan ukuran molekul dan gugus fungsi yang terdapat dalam kedua zat warna tersebut (Rafatullah dkk., 2010). Kongo merah merupakan jenis zat warna anionik dan metilen blue merupakan zat warna kationik.

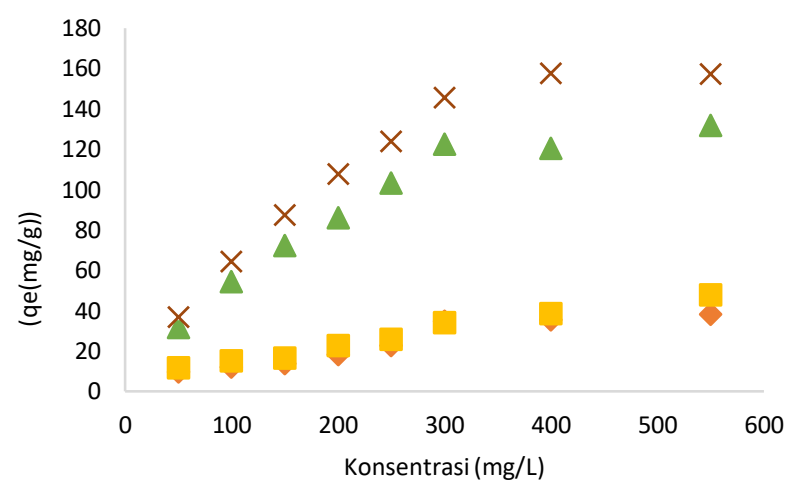

Gambar 9: Kapasitas Adsorpsi untuk Metilen Biru pada Zeolit-X dari Bahan Murni ( $\mathbf{\Delta})$, Zeolit-X dari Abu Dasar (X) dan Kongo Merah pada Zeolit-X dari Bahan Murni ( $\bullet)$, Zeolit-X dari Abu Dasar

\subsubsection{Penentuan Termodinamika Adsorpsi}

Variasi suhu adsorpsi dilakukan pada $30,40,50^{\circ} \mathrm{C}$ dengan konsentrasi larutan yaitu $50,100,150,200$, 250, 300, 400, $550 \mathrm{mg} / \mathrm{L}$. Proses adsorpsi baik kongo merah maupun metilen biru menggunakan bahan adsorben zeolit-X yang dibuat dari bahan murni maupun zeolit-X yang dibuat dari abu dasar diteliti dengan parameter termodinamik diantaranya $\Delta G^{\circ}, \Delta H^{\circ}$ dan $\Delta S^{\circ}$.

Hasil pada Gambar 10 menunjukkan bahwa laju adsorpsi molekul adsorbat terjadi lebih cepat pada suhu rendah dan semakin menurun pada suhu tinggi. Hal tersebut menunjukkan bahwa adanya kenaikan suhu adsorpsi menyebabkan adanya peningkatan energi kinetik adsrobat yang dapat mengurangi kemampuan interaksi antara adsorben dan adsorbat (Chabani dkk., 2006).

Hasil ini sesuai dengan penelitian yang dilakukan oleh Chabani (2006) yaitu pada adsorbsi fisika, adsorbsi semakin kecil dengan meningkatnya suhu. Hal ini karena dengan kenaikan suhu menyebabkan desorpsi semakin besar. Desorpsi merupakan suatu peristiwa terlepasnya molekul, ion atau partikel yang terserap oleh suatu padatan. Dengan terjadinya peristiwa desorpsi ini menyebabkan kapasitas penjerapan menurun seiring dengan naiknya suhu. Variasi suhu pada masing- masing adsorben ditunjukkan pada Gambar 10. 


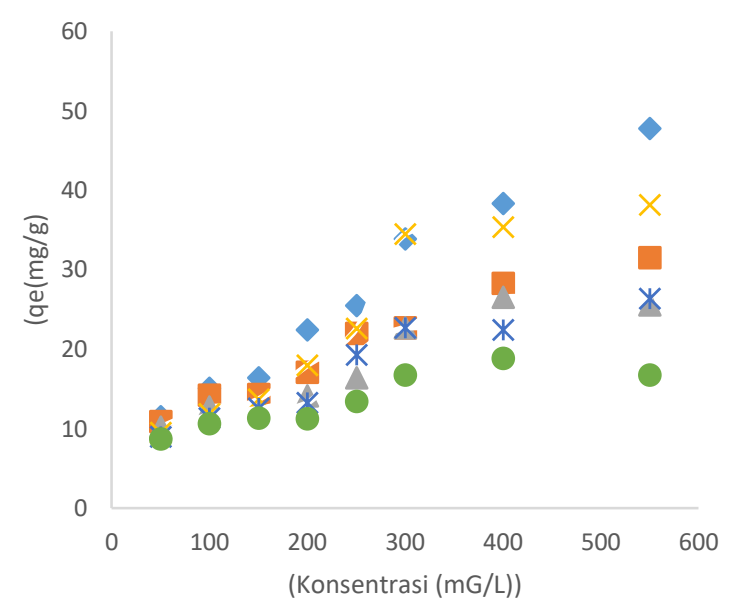

(a)

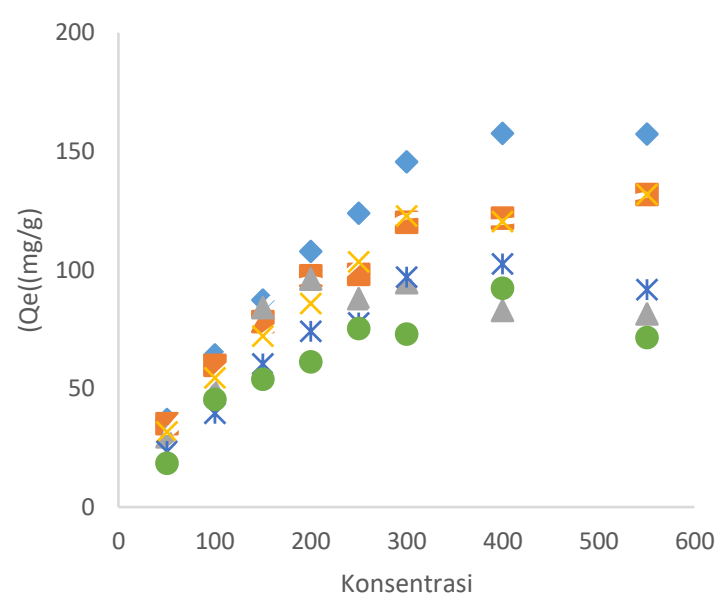

(b)

Gambar 10: Kapasitas Adsorpsi (a) Kongo merah dan (b) Metilen Biru, pada variasi suhu $(\diamond) 30^{\circ} \mathrm{C},(-) 40^{\circ} \mathrm{C},(\boldsymbol{\Delta}) 50^{\circ} \mathrm{C}$ dengan adsorben zeolit-X dari bahan murni dan $(\mathrm{X}) 30^{\circ} \mathrm{C},(*) 40^{\circ} \mathrm{C}$, $50^{\circ} \mathrm{C}$ dengan adsorben zeolit- $\mathrm{X}$ dari abu dasar

Proses adsorpsi baik kongo merah maupun metilen biru menggunakan adsorben zeolit- $X$ yang dibuat dari bahan murni maupun zeolit- $\mathrm{X}$ dari abu dasar diteliti dengan parameter termodinamik diantaranya $\Delta G^{\circ}, \Delta H^{\circ}$ dan $\Delta S^{\circ}$. Parameter termodinamika merupakan aspek penting dalam studi adsorpsi. Parameter tersebut memberikan penjelasan yang lebih baik mengenai pengaruh suhu pada proses adsorpsi. Parameter termodinamika ditunjukkan pada Tabel 7.

Tabel 7: Parameter Termodinamika Adsorbsi

\begin{tabular}{cccccc}
\hline Adsorben & $\Delta \mathrm{H}^{\circ}(\mathrm{kJ} / \mathrm{mol})$ & $\begin{array}{c}\Delta \mathrm{S}^{\circ}(\mathrm{kJ} / \\
\mathrm{mol})\end{array}$ & $\mathbf{3 0 3}^{\circ} \mathbf{K}$ & $\Delta \mathrm{G}^{\circ}(\mathrm{kJ} / \mathrm{mol})$ & $\mathbf{3 1 3}^{\circ} \mathbf{K}$ \\
\hline Zeolit-X & $-4,0532$ & 6,9904 & $-6,171$ & $-6,241$ & $-6,311$
\end{tabular}

Perhitungan energi Gibbs $\left(\Delta \mathrm{G}^{\circ}\right)$ dari proses adsorpsi dapat dilakukan menggunakan persamaan $\left(\Delta \mathrm{G}^{\circ}\right)$ $=-R T \ln K d$ (Chabani dkk, 2006). Nilai entalpi $\left(\Delta H^{\circ}\right)$ dan entropi $\left(\Delta S^{\circ}\right)$ dari proses adsorpsi dapat dihitung menggunakan slope dan intercept dari Persamaan 17.

$$
\ln K d=\frac{\Delta \mathrm{H}^{\circ}}{R T}+\frac{\Delta \mathrm{S}^{\circ}}{R} .
$$

Pada Tabel 7 dapat dijelaskan bahwa nilai $\left(\Delta G^{\circ}\right)$ adsorbsi pewarna dengan adsorben zeolit-X memiliki nilai negative pada setiap suhu adsorbsi. Nilai negatif tersebut menunjukkan bahwa proses adsorpsi berjalan dengan spontan. Nilai negatif dari $\Delta \mathrm{G}^{\circ}$ yang cukup besar menjelaskan bahwa secara energetik, proses adsorpsi tersebut lebih disukai dibanding mekanisme adsorpsi lainnya. Nilai $\Delta \mathrm{G}^{\circ}$ pada penelitian ini semakin menurun dengan kenaikan suhu. Hal tersebut menunjukkan bahwa pada suhu yang lebih tinggi, terjadi penurunan gaya dorong yang mengakibatkan terjadinya penurunan proses adsorpsi molekul adsorbat pada adsorben (Du dkk., 2007).

Nilai entropi $\left(\Delta \mathrm{S}^{\circ}\right)$ menunjukkan nilai positif, yang mengindikasikan adanya peningkatan ketidakteraturan (entropi) yang terjadi pada antar muka padatan-larutan selama proses adsorpsi. Nilai positif juga menunjukkan proses yang terjadi secara spontan. Disisi lain, nilai yang didapat dari $\Delta \mathrm{H}^{\circ}$ negatif, mengindikasikan proses adsorbsi yang berlangsung secara eksotermik.

\section{Kesimpulan}


Berdasarkan penelitian yang telah dilakukan dapat disimpukan bahwa zeolit-X dari abu dasar berhasil disintesis melalui proses peleburan dalam atmosfer udara yang dilanjutkan dengan proses hidrotermal pada suhu $100^{\circ} \mathrm{C}$. Kemudian zeolit-X dari abu dasar digunakan untuk mengadsorp zat warna metilen biru dan kongo merah. Nilai kapasitas adsorpsinya dibandingkan dengan zeolit-X bahan murni. Hasil adsorpsi menunjukkan bahwa material hasil sintetis lebih efektif digunakan sebagai adsorpsi metilen biru. Kapasitas adsorpsi pada kongo merah dan metilen biru berturut-turut 47,71386 mg/g; 157,2597 $\mathrm{mg} / \mathrm{g}$ pada bahan murni dan $38,684 \mathrm{mg} / \mathrm{g} ; 131,6973 \mathrm{mg} / \mathrm{g}$ pada abu dasar. Plot isotermal zat warna metilen biru dan kongo merah mengikuti persamaan Langmuir pada kedua zat warna, sedangkan kinetika adsorpsi yang terjadi mengikuti persamaan orde satu dan dua semu yang keduanya identik dengan adsorpsi kimia. Pada studi termodinamika menunjukkan bahwa adsorpsi bersifat eksotermik dan terjadi secara spontan dengan nilai $\Delta \mathrm{H}^{\circ}$ negatif dan $\Delta \mathrm{G}^{\mathrm{o}}$ negatif pada suhu $303-323{ }^{\circ} \mathrm{K}$.

\section{Daftar Pustaka}

Almeida, C. A. P., Debacher, N. A., Downs, A. J., Cottet, L., \& Mello, C. A. D. (2009) 'Removal of methylene blue from colored effluents by adsorption on montmorillonite clay', Journal of Colloid and Interface Science, Vol. 332, No.1: 46-53.

Azizi, S. N., Ghasemi, S., \& Kavian, S. (2014) 'Synthesis and characterization of NaX nanozeolit using stem sweep as silica source and application of Ag-modified nanozeolit in electrocatalytic reduction of $\mathrm{H}_{2} \mathrm{O}_{2}$ ', Biosensors and Bioelectronics, Vol. 62, No.1: 1-7.

Chabani, M., Amrane, A., \& Bensmaili, A. (2006) 'Kinetic modelling of the adsorption of nitrates by ion exchange resin', Chemical Engineering Journal, Vol. 125, No.2: 111-117.

Chen, H., \& Zhao, J. (2009) 'Adsorption study for removal of Congo red anionic dye using organo-attapulgite', Adsorption, Vol.15, No.4: 381-389.

Derakhshan, Z. (2013) 'Adsorption of Methylene Blue Dye from Aqueous Solution by Modified Pumice Stone: Kinetics and Equilibrium Studies', Health Scope, Vol.2, No.3: 136-144.

Du, X., \& Wu, E. (2007) 'Porosity of microporous zeolites A, X and ZSM-5 studied by small angle X-ray scattering and nitrogen adsorption', Journal of Physics and Chemistry of Solids, Vol. 68, No.9: 1692-1699.

Ferrero, F. (2007) 'Dye removal by low cost adsorbents: Hazelnut shells in comparison with wood sawdust', Journal of Hazardous Materials, Vol. 142, No.1-2: 144-152.

Ho, Y.S. and McKay, G., 1999. Pseudo-second order model for sorption processes. Process biochemistry, 34(5), pp.451-465.

Jin, X., Jiang, M. qin, Shan, X. quan, Pei, Z. guo, \& Chen, Z. (2008) 'Adsorption of methylene blue and orange II onto unmodified and surfactant-modified zeolit', Journal of Colloid and Interface Science, Vol. 328, No.2: 243-247.

Jumaeri, W., Astuti, Lestari, W.T.P. (2007) 'Preparasi dan Karakterisasi Zeolit dari Abu Layang Batubara secara Alkali Hidrotermal', Jurnal Reaktor, Vol. 11, No.1: 38-44.

KLH (Kementrian Lingkungan Hidup). 2008. Status Lingkungan Hidup Indonesia 2007. Kementerian Negara Lingkungan Hidup RI.

Laksono, A.D. and Adlina, N., 2019. Pengaruh Perlakuan Alkalinisasi Serat Alam Kayu Bangkirai (Shorea Laevifolia Endert) pada Sifat Mekanik Komposit dengan Matriks Poliester. JST (Jurnal Sains Terapan), 5(2), pp.60-66.

Langmuir, I. (1998) 'The adsorption of gases on plane surfaces of glass, mica and platinum', Journal of the American Chemical Society, Vol. 40, No.9: 1361-1403.

Munagapati, V. S., \& Kim, D. S. (2017) 'Equilibrium isotherms, kinetics, and thermodynamics studies for congo red adsorption using calcium alginate beads impregnated with nano-goethite', Ecotoxicology and Environmental Safety, Vol. 141, No.1: 226-234.

Rafatullah, M., Sulaiman, O., Hashim, R., \& Ahmad, A. (2010) 'Adsorption of methylene blue on low-cost adsorbents: A review', Journal of Hazardous Materials, Vol. 177, No.1-3: 70-80.

Thanh Tu, N. T., Thien, T. V., Du, P. D., Thanh Chau, V. T., Mau, T. X., \& Khieu, D. Q. (2018) 'Adsorptive removal of Congo red from aqueous solution using zeolitic imidazolate framework-67', Journal of Environmental Chemical Engineering, Vol. 6, No.2: 2269-2280.

Wang, J. Q., Huang, Y. X., Pan, Y., \& Mi, J. X. (2016) 'New hydrothermal route for the synthesis of high purity nanoparticles of zeolit y from kaolin and quartz', Microporous and Mesoporous Materials, Vol. 232, No.1: $77-85$.

Widiastuti N., Wu H., Ang H. M., Zhang D. (2011) 'Removal of ammonium from greywater using natural zeolite', Desalination, Vol. 277, No.1: 15-23.

Yanti, Y. (2009) 'Sintesis Zeolit A dan Zeolit Karbon Aktif dari Abu Dasar PLTU Paiton dengan Metode Peleburan', Tesis Megister, Institut Teknologi Sepuluh Nopember: Surabaya. 
Adsorpsi Metilen Biru dan Kongo Merah pada Zeolit-X Hasil Sintesis dari Abu Dasar

Zhang, X., Tang, D., Zhang, M., \& Yang, R. (2013) 'Synthesis of NaX zeolit: Influence of crystallization time, temperature and batch molar ratio $\mathrm{SiO}^{2} / \mathrm{Al}_{2} \mathrm{O}_{3}$ on the particulate properties of zeolit crystals', Powder Technology, Vol. 235, No.1: $322-328$. 